\title{
Whether the Allocation of International Aid Is Biased to Recipient Countries' Exchange Rate Regime and Capital Openness?
}

\author{
Yaqi Sun ${ }^{1}$, Yuanjun Zhao ${ }^{2 *}$ \\ ${ }^{1}$ Guanghua School of Management, Peking University, Beijing, China \\ ${ }^{2}$ Agricultural Bank of China, Beijing, China \\ Email: sunyaqi@pku.edu.cn, ^willwayhopesucess@163.com
}

How to cite this paper: Sun, Y. Q., \& Zhao, Y. J. (2020). Whether the Allocation of International Aid Is Biased to Recipient Countries' Exchange Rate Regime and Capital Openness?. Theoretical Economics Letters, 10, 997-1017.

https://doi.org/10.4236/tel.2020.104058

Received: June 12, 2020

Accepted: August 28, 2020

Published: August 31, 2020

Copyright (อ 2020 by author(s) and Scientific Research Publishing Inc. This work is licensed under the Creative Commons Attribution International License (CC BY 4.0).

http://creativecommons.org/licenses/by/4.0/

\begin{abstract}
This study investigates whether distribution of international assistance is influenced by recipient countries' exchange rate regime and capital openness. Our empirical analysis finds that countries that have more fixed exchange rate regime have more possibility to receive larger foreign aid while the capital openness has no significant effects after controlling for the country pair fixed effect. Bilateral trade interest may be a potential explanation of the effects.
\end{abstract}

\section{Keywords}

Component, International Financial Aid, Exchange Rate, Capital Openness

"The purpose of an international program of aid to underdeveloped countries is to accelerate their economic development up to a point where a satisfactory rate of growth can be achieved on a self-sustaining basis."

- P.N. Rosenstein-Rodan

\section{Introduction}

As cited, international aid is designed for facilitating development in underdeveloped countries. Although this purpose is widely stated, researchers have divergent opinions on the effect of international aid on growth (Clemens et al., 2012). Rajan and Subramanian (2008) found little robust evidence of a positive (or negative) relationship between aid inflows received and its economic growth, even after correcting for the potential bias that poorer (or stronger) growth may 
attract more aid. However, some researchers used instrument variables to demonstrate that aid had statistically and economically significant effect on growth. Given lots of insignificant results in simple cross-country models (Ram, 2004), researchers started to study the conditions of effectiveness, such as good policy environment (Burnside \& Dollar, 2004; Easterly, 2003; Hansen \& Tarp, 2001). Surprisingly, though many researchers analyzed various policies, there is little research on the correlation between aid and recipient countries' international finance policies.

Also, as the size of international aid increases (see Figure 1) and several developing countries also actively engage in donating aid, the allocation bias tends to be another important issue. Thus, researchers turned from measuring effectiveness to studying the motivations of aid allocation to better understand the process rather than estimating the outcomes. Responding to this gap, in this paper, we plan to combine the latter two traits, that is, testing whether the bilateral aid allocation is biased to the recipient countries' policy, especially international finance policies.

We focus on international finance policies because we are inspired by the famous Impossible Trinity, with exchange rate regime, monetary policy independence, and financial openness of capital account on each triangle corner. It demonstrates that any country cannot obtain control of all these three policies at the same time. Therefore, we can use only two polices out of three to depict a relatively complete picture of international finance policies in a certain country. Therefore, exchange rate regime and capital openness are chosen to be main dependent variables in our research.

Furthermore, it should be clarified that we study bilateral aid instead of including multilateral aid for better interpretation of motivations. Multilateral organization's motivation and allocation bias are potentially different from countries (Maizels \& Nissanke, 1984).

Following these specifications, in Background section, we will review the time trend of aggregated and categorized bilateral aid, the performance of different agents (including OECD countries, multilateral organizations and developing countries), and the international financial policies in donor and recipient countries. Next, we present the historical evolution of research interests on this topic, from general to specific perspectives. In Section 4, we establish the benchmark model referring to previous literature. In addition to model specification, we also detailed state our data source and data processing process, because the dataset is merged by data from multiple sources. Particularly, we will present a policy space graph to demonstrate the concerns about the potential correlation between exchange rate regime and capital openness in this section. Results and discussions are reported in Section 5. In addition to multiple estimation of benchmark model, we also conduct robustness check on different time periods and different categories. Then, we attempt to identify donor's interests that correspond to this correlation between aid allocation and international finance policies. Remarka- 
bly, we further estimate the model with the interaction of fixed exchange rate and trade volume to test whether this indirect evidence will support our hypothesis. Finally, in Section 6, we conclude the evidence and point out the limitation of this paper.

\section{Background}

\subsection{Time Trend of Bilateral Aid Flows}

The international aid size increases dramatically in recent decades and several developing countries also actively engage in donating aids to other developing countries, drawing much more attention to this topic.

As shown in Figure 1, total bilateral aid generally has increased since 1970. Bilateral aid flows jump at around 1971, that is, the year of the breakdown of Bretton Woods System. Since then the total commitment amount grows steadily and fluctuated yearly. The fluctuation was reasonable for the bilateral aid allocation was decided by each country, aggregated by each category and it would correspond to immediate situations, such as natural disasters and political crisis. Also, we graph the categorized bilateral aid flows, which will be demonstrated in following sections.

\subsection{Aid Allocation of Different Agents}

Aid flows form Development Assistance Committee members of OECD countries have been paid a lot of attention since it covered main donors countries. Hoeffler and Outram (2011) further found that most bilateral donors place little importance on recipient merit while Japan and UK, as exceptions, allocate more aid to countries with higher democracy scores and fewer human rights abuses. Other political factors, including colonies relationship (Alesina \& Dollar, 1998),

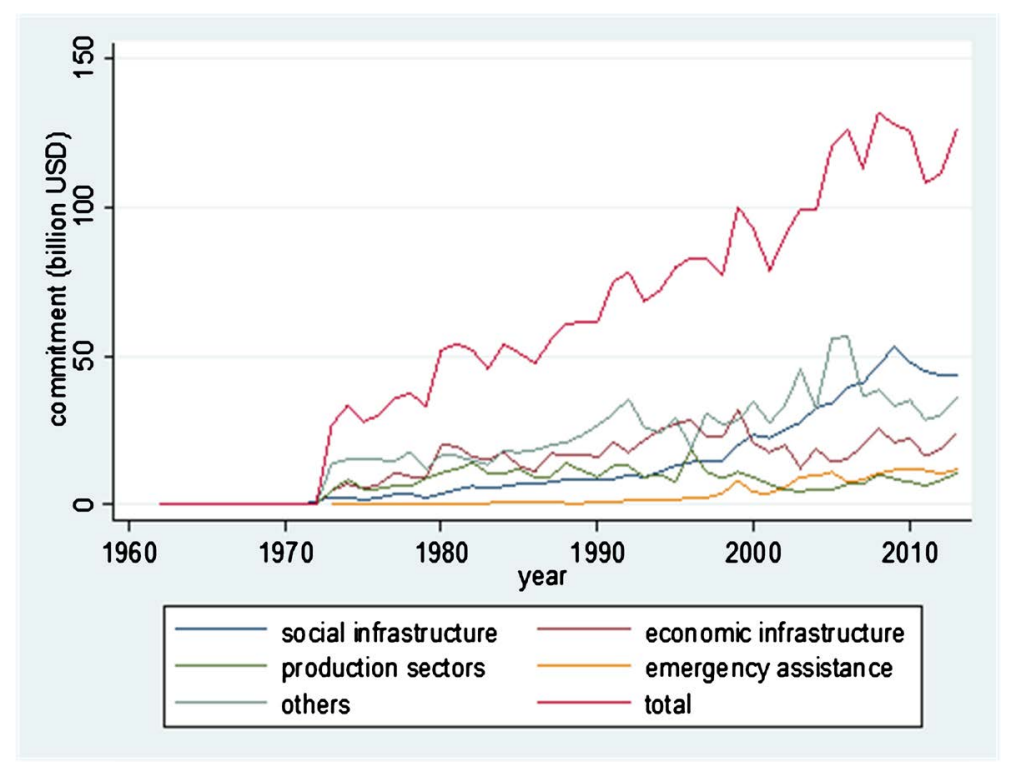

Figure 1. Time trends of bilateral aid flows of different purposes. 
bilateral trade volume, and voting similarity in UNGA and UNSC membership (Stubbs et al., 2015), are also found to have a significantly positive effect on the probability or amount of aid flows. Besides, bilateral aid is also found to increase as a reward of political liberalization of the recipient countries (Reinsberg, 2015). A more direct test made by (Faye \& Niehaus, 2012) even showed the evidence of an election-year effect of official development assistance from OECD countries, implying that donors may use aid as support to parties they like.

Aid from other institutions like World Bank and WTO showed a non-economical selectivity bias in aid allocation as well. Kilby (2013) found substantially shorter project preparation periods for World Bank loans to countries that are geopolitically important (especially to the U.S.). For trade aid flows allocation, Lee et al. (2015) found there was a WTO member effect. Compared to non-WTO developing members, the WTO developing members received more Aid for Trade dollar commitments and larger number of Aid for Trade projects during 2001-2010.

Despite the traditional main donors from developed countries, developing countries, especially China and India, are also rising to important donors of aid flows. Dreher and Fuchs (2015) found China does not pay substantially more attention to politics compared to Western donors. Instead, China's aid allocation seems to be widely independent of recipients' endowment with natural resources and institutional characteristics. By contrast, Fuchs and Vadlamannati (2013) found the importance of political interests to be significantly larger for India than for all donors of the Development Assistance Committee. Moreover, countries that are geographically closer are more likely to enter India's aid program.

Among all the agents, we focus on bilateral aid. Hence, we review the allocation by listing the top 10 donor countries and top 10 recipient countries by total amount in Table 1 . The top 10 donors are all OECD countries, while the top recipients are mostly highly populated Asian countries.

\subsection{International Finance Policies}

To better understand these two policies, we present mean level of flexibility and capital openness of both donor and recipient countries in our sample.

As shown in Figure 2, we traced the time trends of exchange rate regime and capital openness of donor and recipient countries respectively. Our measure of exchange rate regime is based on Reinhart and Rogoff (2004). If a country is classified as 1 or 2 in its coarse edition, it is classified as having a fixed exchange rate regime. Otherwise it is regarded as a country with floated exchange rate regime. We adopt the widely accepted Chin-Ito Index to measure the capital openness of a country. This index is normalized between 0 and 1 . The higher value means the higher openness of the country's capital mobility. We present mean level of flexibility and capital openness of both donor and recipient countries in our sample.

In general, donor countries have a larger capital openness than recipient countries. And the donors and recipients have similar time trends in capital 
Table 1. Top 10 donors and recipients.

\begin{tabular}{cccc}
\hline \multicolumn{2}{c}{ Top 10 donors } & \multicolumn{2}{c}{ Top 10 recipients } \\
\hline Donors & $\begin{array}{c}\text { Commitment } \\
\text { (billion USD) }\end{array}$ & Recipients & $\begin{array}{c}\text { Commitment } \\
\text { (billion USD) }\end{array}$ \\
\hline United States & 858.1 & Indonesia & 134.5 \\
Japan & 561.9 & India & 134.0 \\
Germany & 331.1 & Egypt & 115.9 \\
France & 233.6 & China & 110.9 \\
United Kingdom & 158.8 & Iraq & 86.4 \\
Netherlands & 133.9 & Pakistan & 75.4 \\
Canada & 109.0 & Bangladesh & 67.4 \\
Sweden & 91.0 & Philippines & 66.6 \\
Australia & 83.7 & Israel & 57.1 \\
Norway & 77.3 & Afghanistan & 56.1 \\
& & & 3093.3 \\
\hline
\end{tabular}

Data source: AIDDATA (www.aiddata.org).

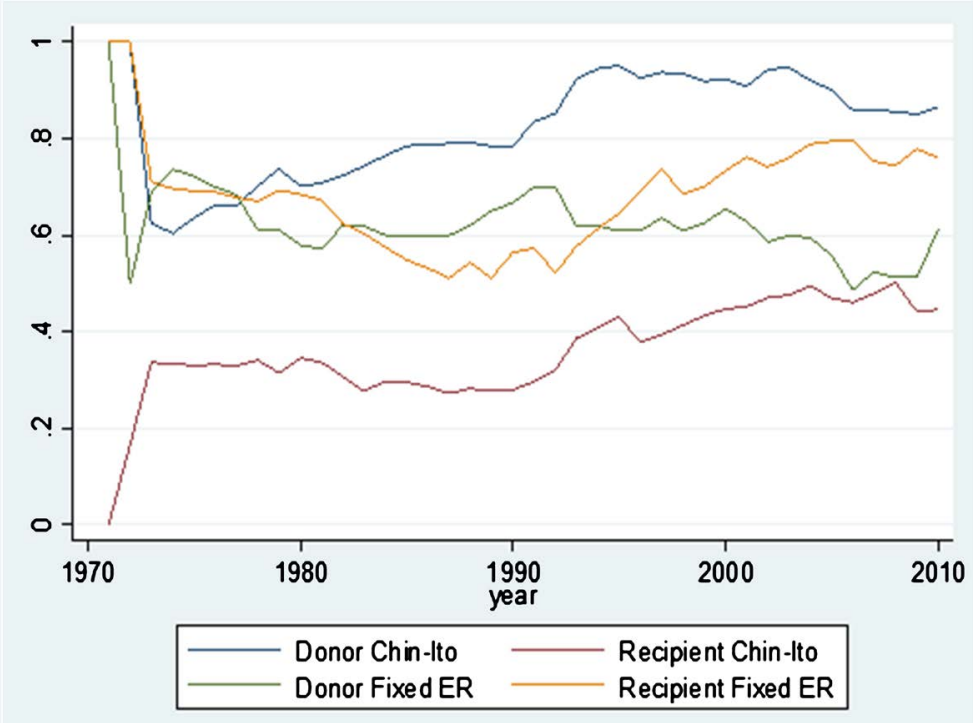

Figure 2. Time trends of exchange rate regime and capital openness.

openness. The mean levels of capital openness for both groups keep steady before 1990s. Since 1992, however, there is a dramatic increase of capital openness for both groups. This increasing tread has an abrupt stop at around 2008 and 2009 , the global financial crisis.

By contrast, the flexibility of exchange rate regime shows a more complicated time trend. For donor countries, exchange rate regime turns to be more flexible since the breakdown of Bretton Woods System. In 1980s, however, there is a decrease of the flexibility. This decrease also ends along with the cold war. From 
1992 to 2008, the donor countries experience a clear picture of increasing flexibility. After financial crisis in 2008, this trend of increasing flexibility also changes. For recipient countries, the critical points of changes are similar. However, the volatility is larger. In particular, since the end of cold war, the recipient countries experience a dramatic decrease in the exchange rate regime.

In conclusion, we plan to analyze whether the choice among these corners is correlated with the recipient countries' possibility of receiving aid and the amount of aid. This correlation may reflect the donor countries' interests. In other words, we want to evaluate whether this potential bias of international aid towards certain financial policy is significant and sustainable.

\section{Literature Review}

International aid, as an important form of international cooperation, has been applied to facilitate the development in underdeveloped countries. Researchers have been interested in the motivation of foreign aids for decades. Their interests evolved with the changes in the world. Previous research tried to generally answer the question about the comparative weights in objective functions between donors' interests and recipients' needs. They found that political, economic and strategic interests of donors rather than the development objectives determined aid allocation (McKinlay \& Little, 1979; Maizels \& Nissanke, 1984; Dowling \& Hiemenz, 1985; Svensson, 1999; Neumayer, 2003).

For instance, Hoeffler and Outram (2011) made a comprehensive test on aid flows combining donor and recipient characteristics. They concluded that all bilateral donors allocate aid based on their self-interest and recipient need. Dollar and Levin (2006) constructed another measurement, by further examining the allocation of foreign aid through "policy selectivity" index and "poverty selectivity" index. The former index refers to whether aid is targeted to countries with sound institutions and policies, while the latter one measures whether aid focuses on poor countries. These two measurements emphasize on the comparison between the effectiveness and the fairness of international aid.

Furthermore, researchers tried to identify those political and economic interests that affect aid flows. Several mechanisms of biases are empirically measured, such as colonial past, political alliances, democracy and country size (Berthélemy, 2006; Snyder, 1993). In addition, Neumayer (2005) used food aid to examine whether the aid allocation was free from donor interest bias. He found that geographically distance matters, while the military strategies and export interests do not matter. More recent studies found that countries who had colonial ties with donor countries or supported donor countries in the U.N. voting receive more aid (Alesina \& Dollar, 1998; Kuziemko \& Werker, 2006). Although these studies provided insightful picture of donor countries' preference in aid allocation, they focused on political behavior without extending to other fields.

Besides the identification of donor's interests that may distort aid allocation, the comparison between donor's interests and recipient's need, in other words, 
bias or efficiency, can be studied in the other direction-illustrating whether the policy environment of the recipient country would affect aid flows. Alesina and Weder (2002) found that corrupt governments received as much aid as less corrupt governments. Burnside and Dollar (2000) found no significant effect of good policy environment on the receiving more aid. Healthy policy environment facilitated the efficiency of aid in recipient countries; thus, these studies indirectly revealed that donors paid less attention to the efficiency of the aid on promoting development. Although previous studies analyzed the effect of general policy environment and political interests, there is little literature focus on economic interests and policies, especially international finance policies. Considering the importance of exchange rate and capital openness on the trade and capital flows between countries, it is astonishing that no research has ever connected the aid flows with the recipient countries' exchange rate regime and capital openness. The issue of aid effectiveness and fairness is still a black box (Bourguignon \& Sundberg, 2007). Therefore, we study whether the allocation of international aid is biased to recipient countries' exchange rate regime and capital openness.

\section{Model Specification and Data}

\subsection{Benchmark Model}

We initially establish the benchmark model that covers main variables measuring recipient country's financial policy and control variables that were commonly examined in the previous literature. Next, we estimate the correlation and check the stability. Then, we indirectly test the hypothesis further by interacting the main variables with donor countries' economic interests, such as trade.

$$
\begin{aligned}
\text { Aid }_{i j t}= & \beta_{1} \text { Capital Openess }+\beta_{2} \text { Exchange Rate Regime } \\
& +\beta_{3} \text { Control Varibales }+\alpha_{j}=\alpha_{t}=\mu_{i j t}
\end{aligned}
$$

As shown in Equation (1), $\operatorname{Aid}_{i j t}$ refers to the bilateral aid delivered from donor country $j$ to recipient country $i$ in year $t$. Capital Openness and Exchange Rate Regime respectively measure the financial policy of recipient country $i$ in year $t$. Control variables include economic and policy factors, which are commonly tested in previous literature. Also, we introduce donor country fixed effect to control for the time invariant features of the donor, as well as year fixed effect. To avoid potential bias from unobservable country-pair specific factors, we further replace the donor country fixed effect with donor-recipient pair fixed effect. Since colonial connection has been covered into the pair fixed effect, we no longer control it in this regression.

\subsection{Data}

As stated in the benchmark model, Bilateral Aid Flows, GDP per capita, Population, are all log values. Exchange Rate Regime, Democracy, Political Rights and Colonial Connection are all dummy variables. Capital Openness is categorical 
variables. Aid flow data is from aiddata.org, contributed by Tierney et al. (2011). Our aid data is from AidData's Core Research Release Version 3.0. This dataset tracks are known international development flows from bilateral and multilateral aid organizations. The dataset record more than 655 thousand aid flows from 96 different donors, starting from 1947 and updated to 2013. The values of the commitments are denoted in 2011 USD constant price. The total commitments reach as high as 7042 billion USD. The dataset includes information on donor, recipient, time, commitment amount and purpose categories of each aid flows. So we can make a detailed analysis on the aid flows. To our knowledge, this is the most comprehensive dataset available for research. In this paper we focus on bilateral aid flows. So we drop those aid flows whose donor or recipient belongs to organizations.

For the exchange rate regime, though IMF provides classification of exchange rate regimes based on announcement by the governments, there exist quite a lot of inconsistencies between reported and actual policies in many cases. So we turn to a de facto classification constructed by Reinhart and Rogoff (2004). They constructed the index based on the market exchange rates and classified regimes into fifteen fine classifications and six coarse ones. In the annual database, the authors trace the index back to 1991 for most countries and for some countries it provides data as early as 1940s. Based on similar motivation, Levy-Yeyati and Sturzenegger (2005) constructed another measure of de facto classification over the period 1974-2000. Countries are categorized into five types depending on the flexibility of their exchange rate pegs, that is, Fix, Crawling Peg, Dirty float, Flexible and Inconclusive. However, since this classification is no longer updated after 2000, while classifications of Reinhart and Rogoff (2004) cover a longer time span and more countries, we adopt this classification in our paper. It should be noted that the exchange rate regime classified in Reinhart and Rogoff (2004) as 1 or 2 in the coarse edition is classified as fixed exchange rate regime. Otherwise it is regarded as floated exchange rate regime.

Chinn and Ito (2006) had developed a famous index of capital account openness, which is named after them. This index is based on information regarding restrictions in the IMF's Annual Report on Exchange Arrangements and Exchange Restrictions. The newest version of the index has traced back to 1970s for 182 countries. It is a normalized index between zero and one, the larger of the value, the higher degree of capital mobility. Based on the Impossible Trinity Theory, we only need to cover 2 corners of the trinity. Another potential explanation variable is monetary independence. The measurement of monetary independence is subtler. It does not have a standardized index such widely recognized. Also the variation on monetary independence is limited across countries (Aizenman et al., 2013). Therefore, we choose to use exchange rate regime and capital openness to measure countries' international finance policy.

Following the previous literature, we control variables that considered to be basic economic fundamental factors, including countries' population, per capita 
GDP, GDP growth. All of the variables are available from World Development Indicators issued by World Bank and Penn World Table.

We will also control other factors that have been found to affect aid flows. Following Dollar and Levin (2006), we will control the effects of several dimensional factors that may bias our benchmark results. Among them we focus on political institutional factors, including Rule of law index from International Country Risk Guide contributed by Bertelsmann Stiftung 2014, democracy measurement form Boix, Miller, and Rosato (2013), political rights measurement like Freedom House Democracy index (2015). In detail, we control for democracy of the recipient countries using a dichotomous coding of democracy constructed by Boix et al. (2013). A country is defined as democratic if it satisfies conditions for both contestation and participation. We control political rights based on a grade classified by Freedom House (2015). This grade is a measure of the people's freedom to participate in the political process. The original grade is from 1 (most free) to 7 (least free). We change it into a dummy by classifying those grades less or equal to 4 as 1 , otherwise as 0 . The new dummy means the citizens in the country have more political rights if it is 1 . Besides, variables measuring bilateral relationship between donors and recipient countries including trade values and colonial relationship will also be considered in further robustness test. Our measurement of colonial connection is based on Hadenius and Teorell (2007). We define a dummy variable, colonial, as 1 if and only if the donor country has colonial relationship with recipient country. In further analysis, we also introduce bilateral trade values into the model. Our bilateral trade data come from World Trade Table (Feenstra et al., 2004). The values are measured in one thousand US dollar. We calculate values of import from donor to recipient, export from recipient to donor and sum of export and import to measure the bilateral trade relationship between donor and recipient countries.

\subsection{Summary Statistics}

Summary statistics are described in Table 2.

As stated, we focus on the role of exchange rate regime and financial openness of the recipient country's capital account. However, the potential correlation between these two financial policies may impose threats to our model that relies on Impossible Trinity theory. Figure 3 shows the international financial policy location of countries and regions.

Each country and region is spotted by yearly averaged index of flexibility of exchange rate and capital openness. Countries and regions are almost evenly spread in the policy location graph, though many economically underdeveloped countries locate at the left corner, which represents fixed exchange rate and low capital openness. Referring to this evenly located graph and Impossible Trinity theory, we establish the benchmark model including both flexibility of exchange rate and capital openness.

Furthermore, to alleviate this concern about the correlation between two main 
Table 2. Summary statistics.

\begin{tabular}{cccc}
\hline VARIABLES & Mean (s.d.) & VARIABLES & Mean (s.d.) \\
\hline Aid Flows & 15.09 & Political Rights & 0.546 \\
GDP per capita & $(2.706)$ & & $(0.498)$ \\
& 10.55 & Colonial Connection & 0.0536 \\
Population & $(1.864)$ & & $(0.225)$ \\
& 2.379 & Export Value to Donor & 3.899 \\
Fixed ER & $(1.724)$ & & $(5.295)$ \\
& 0.688 & Import Value from Donor & 4.119 \\
Chin-Ito Index & $(0.463)$ & & $(5.377)$ \\
& 2.051 & Bilateral Trade Value & 4.473 \\
Democracy & $(0.765)$ & & $(5.718)$ \\
& 0.449 & & \\
\hline
\end{tabular}

Note: Aid Flows, GDP per capita, Population, Export, Import and Bilateral Trade Values are all log values. Fixed ER, Democracy, Political Rights and Colonial Connection are all dummy variables.

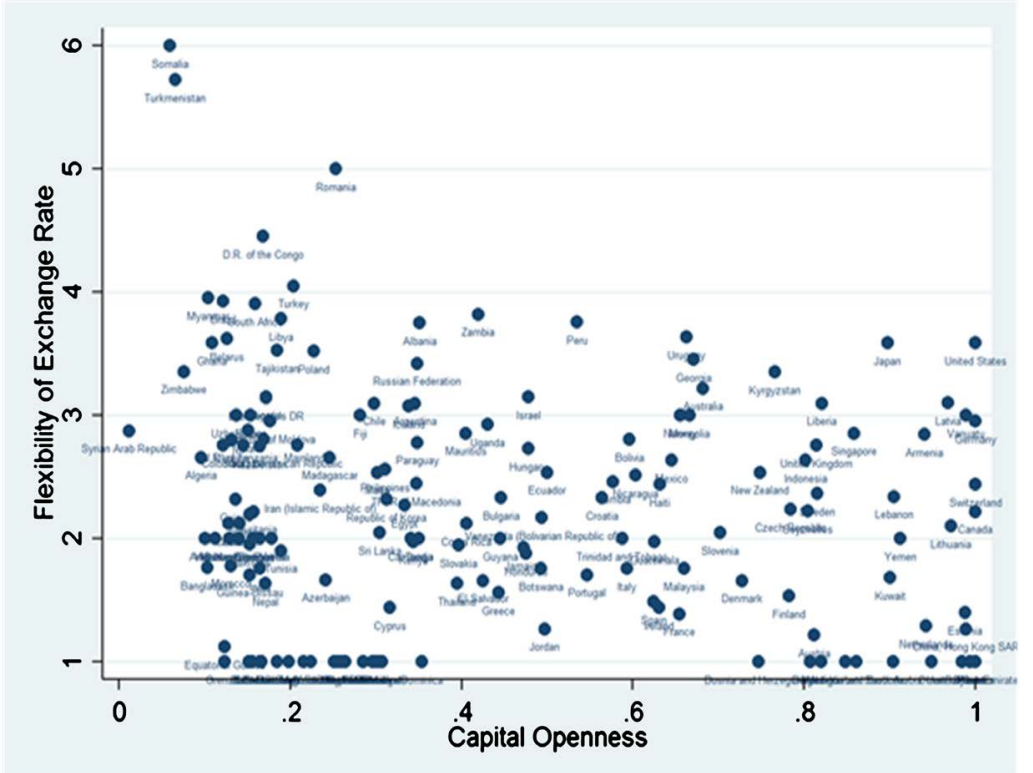

Figure 3. International finance policy space.

independent variables, we also conduct a robustness check same with our benchmark model without capital openness (see Appendix). Since the results are similar to our benchmark model, it is not specifically reported in the paper.

\section{Results}

\subsection{Benchmark Results}

Our benchmark results are summarized in Table 3. 
Table 3. Benchmark results.

\begin{tabular}{|c|c|c|c|c|c|}
\hline Variables & (1) & (2) & (3) & (4) & (5) \\
\hline \multirow[t]{2}{*}{ Fixed ER } & $0.169^{* * *}$ & $0.108^{* * *}$ & $0.107^{\star * *}$ & & $0.172^{* * *}$ \\
\hline & $(0.0267)$ & $(0.0223)$ & $(0.0219)$ & & $(0.0243)$ \\
\hline \multirow[t]{2}{*}{ Chinn-Ito Index } & $0.0215^{\star *}$ & $0.0423^{* * *}$ & $0.0405^{* * *}$ & & 0.00555 \\
\hline & $(0.00940)$ & $(0.00785)$ & $(0.00775)$ & & $(0.0104)$ \\
\hline \multirow[t]{2}{*}{ Lagged Fixed ER } & & & & $0.0930^{* * *}$ & \\
\hline & & & & $(0.0218)$ & \\
\hline \multirow[t]{2}{*}{ Lagged Chinn-Ito Index } & & & & $0.0331^{\star * *}$ & \\
\hline & & & & $(0.00786)$ & \\
\hline \multirow[t]{2}{*}{ GDP per capita } & $-0.364^{\star * *}$ & $-0.391^{* * *}$ & $-0.400^{* * *}$ & $-0.400^{\star * \star}$ & $-0.127^{\star * *}$ \\
\hline & $(0.0132)$ & $(0.0110)$ & $(0.0112)$ & $(0.0112)$ & $(0.0293)$ \\
\hline \multirow[t]{2}{*}{ Population } & $0.796^{* * *}$ & $0.892^{\star * *}$ & $0.915^{\star * *}$ & $0.914^{\star * *}$ & $1.657^{\star * *}$ \\
\hline & $(0.0143)$ & $(0.0121)$ & $(0.0122)$ & $(0.0122)$ & $(0.116)$ \\
\hline \multirow[t]{2}{*}{ Democracy } & & & $0.122^{\star * *}$ & $0.115^{\star * *}$ & $0.157^{* * *}$ \\
\hline & & & $(0.0325)$ & $(0.0327)$ & $(0.0338)$ \\
\hline \multirow[t]{2}{*}{ Political Rights } & & & $0.153^{* * *}$ & $0.158^{* * *}$ & $0.146^{* * *}$ \\
\hline & & & $(0.0324)$ & $(0.0326)$ & $(0.0310)$ \\
\hline \multirow[t]{2}{*}{ Colonial Connection } & & & $2.286^{* * *}$ & $2.286^{\star * *}$ & \\
\hline & & & $(0.0513)$ & $(0.0515)$ & \\
\hline \multirow[t]{2}{*}{ Constant } & $16.85^{* * *}$ & $18.73^{\star * *}$ & $18.62^{\star * *}$ & $18.61^{* * *}$ & $13.74^{* * *}$ \\
\hline & $(0.115)$ & $(1.469)$ & $(1.434)$ & $(1.434)$ & $(1.291)$ \\
\hline Year Fixed Effects & $\mathrm{Y}$ & $\mathrm{Y}$ & $\mathrm{Y}$ & $\mathrm{Y}$ & $\mathrm{Y}$ \\
\hline Donor Fixed Effects & $\mathrm{N}$ & $\mathrm{Y}$ & Y & Y & $\mathrm{N}$ \\
\hline $\begin{array}{l}\text { Donor-Recipient } \\
\text { Pair Fixed Effects }\end{array}$ & $\mathrm{N}$ & $\mathrm{N}$ & $\mathrm{N}$ & $\mathrm{N}$ & $\mathrm{Y}$ \\
\hline Observations & 43,660 & 43,660 & 43,461 & 43,186 & 43,461 \\
\hline R-squared & 0.155 & 0.414 & 0.442 & 0.443 & 0.722 \\
\hline
\end{tabular}

Note: Dependent variable is log values of aid flows. Standard errors in parentheses. ${ }^{\star * *} p<0.01,{ }^{\star *} p<0.05$, ${ }^{*} p<0.1$.

The first column controls only year fixed effects, GDP per capita and population. We find that recipient countries with fixed exchange rate regime receive $16.9 \%$ more aid than those with floated exchange rate regime. This effect is both statistically and economically significant. In the second column, we further control donor country fixed effect. The coefficient of fixed exchange rate regime lowers to $10.8 \%$ but still statistically significant. In the third column, we add control variables measuring institutions and policies of the recipient countries, including degree of democracy, freedom of political rights as well as colonial connection in history between the recipient country and the donor country. We 
find the coefficient of fixed exchange rate regime does not change much. Furthermore, we concern that donor countries may plan ahead rather than immediate decisions. Hence, we introduce the lagged value $(t-1)$ of main variables into the model. The effect remains significantly positive, though the magnitude decreases a little. In column five, we control fixed effects of donor and recipient countries pair. In other words, we control effects of all unobservable fixed effects on the characteristics of each country pair. We find that the effect of fixed exchange rate regime on aid flows turns to be larger, reaching as much as $17.2 \%$.

The role of capital openness on aid flows, however, is only significant in the previous four columns. Without controlling the country pair fixed effects, the higher capital openness of the recipient countries, the more aid the countries receive. But after we control country pair fixed effects, as shown in column 5, the effect of capital openness on aid flows turns to be not significant anymore.

For other control variables, the significance and signs are stable across different specifications. Bilateral aid tends to be allocated to countries with lower GDP per capita and larger population. It is consistent with the fact that poor countries with more people suffering from poverty should be the focus of bilateral aid. Also, the results of democracy, political rights and colonial connection are also consistent with previous literature.

\subsection{Robustness Check}

Researchers found that the motivations of aid allocation may shift in different time periods (Maizels \& Nissanke, 1984). Therefore, to further explore the effect of exchange rate regime on aid flows, we divide our samples into different time periods.

We introduce both year fixed effects and pair fixed effects, without colonial connection for it may interfere with pair fixed effect. The first critical time point we choose is 1992, that is, the year after the dissolution of the Soviet Union and the end of the Cold War. During the Cold War, many aid flows were allocated to specific countries for political union and post-war recovery. While after 1992, bilateral aid tended to be more balanced, instead of focusing on political support. This potential difference before and after 1992 may also change donor countries' aid allocation, which could be reflected in the correlation with recipient countries' financial policies. Therefore, we run sub-sample regressions with results listed in first two columns of Table 4 . The second critical time point we choose is the year of 2002, that is, the year after the $9-11$. The results are summarized in the last two columns of Table 4.

We find that during the cold war, the role of exchange rate regime on aid flows is still positive but not significant. However, after the Cold War, fixed exchange rate regime tends to raise aid flows to the recipient country as much as $14.4 \%$ relative to floated exchange rate regime. Surprisingly, the effect of capital openness is significantly negative before and after 1992, which is the opposite of the benchmark model. Considering that in column 5 of Table 3, the coefficient 
Table 4. Different time periods.

\begin{tabular}{|c|c|c|c|c|}
\hline VARIABLES & $\begin{array}{c}(1) \\
\text { Before } 1992\end{array}$ & $\begin{array}{c}(2) \\
\text { After } 1992\end{array}$ & $\begin{array}{c}(3) \\
\text { Before } 2002\end{array}$ & $\begin{array}{c}(4) \\
\text { After } 2002\end{array}$ \\
\hline \multirow[t]{2}{*}{ Fixed ER } & 0.0778 & $0.144^{* * *}$ & $0.139^{* * *}$ & $0.0959^{* *}$ \\
\hline & $(0.0590)$ & $(0.0294)$ & $(0.0364)$ & $(0.0441)$ \\
\hline \multirow[t]{2}{*}{ Chinn-Ito index } & $-0.0820^{\star *}$ & $-0.0300^{* *}$ & $0.0289^{*}$ & -0.00130 \\
\hline & $(0.0330)$ & $(0.0133)$ & $(0.0169)$ & $(0.0258)$ \\
\hline \multirow[t]{2}{*}{ GDP per capita } & $-0.260^{\star \star \star}$ & -0.00576 & $-0.0948^{\star *}$ & $-0.116^{\star}$ \\
\hline & $(0.0824)$ & $(0.0404)$ & $(0.0477)$ & $(0.0680)$ \\
\hline \multirow[t]{2}{*}{ Population } & 0.700 & $2.477^{* * *}$ & $0.814^{* * *}$ & $2.887^{\star * *}$ \\
\hline & $(0.436)$ & $(0.176)$ & $(0.223)$ & $(0.298)$ \\
\hline \multirow[t]{2}{*}{ Democracy } & 0.0712 & 0.0583 & $0.154^{* * *}$ & $0.136^{* *}$ \\
\hline & $(0.0762)$ & $(0.0407)$ & $(0.0515)$ & $(0.0570)$ \\
\hline \multirow[t]{2}{*}{ Political Rights } & $0.113^{\star}$ & $0.128^{* * *}$ & $0.208^{* * *}$ & $0.140^{* * *}$ \\
\hline & $(0.0667)$ & $(0.0375)$ & $(0.0436)$ & $(0.0533)$ \\
\hline \multirow[t]{2}{*}{ Constant } & $17.73^{\star * *}$ & $9.346^{* * *}$ & $15.34^{\star * *}$ & $8.554^{\star \star \star}$ \\
\hline & $(1.753)$ & $(0.534)$ & $(1.446)$ & $(0.979)$ \\
\hline Year Fixed Effects & $\mathrm{Y}$ & $\mathrm{Y}$ & $\mathrm{Y}$ & $\mathrm{Y}$ \\
\hline Donor-Recipient Pair Fixed Effects & $\mathrm{Y}$ & $\mathrm{Y}$ & $\mathrm{Y}$ & $\mathrm{Y}$ \\
\hline Observations & 10,806 & 32,655 & 21,997 & 21,464 \\
\hline R-squared & 0.025 & 0.019 & 0.022 & 0.014 \\
\hline Number of pairs & 1429 & 3614 & 2281 & 3498 \\
\hline
\end{tabular}

of capital openness is not significant, the effect is ambiguous. In addition, the coefficients of control variables tend to be unstable in sub-samples. This change may reflect the switch of aid focus after the Cold War.

The effects of fixed exchange rate before and after 9 - 11 are both significantly positive. Noted that, the sample size is quite similar before and after 2002, indicating reasonable comparison between the sub-samples. Notably, all coefficients are stable and consistent with our benchmark model, except capital openness.

To better understand this constitution change, similar to Table 1, we report the top 10 donors and top 10 recipients by total amount, before and after 1992, respectively in Table 5.

The members of top 10 donor countries tended to be similar, while the recipient countries changed more. For instance, Tanzania, the only African countries disappeared from the top 10 recipient lists after 1992. Also, severely impacted by the end of Cold War, Russian Federation became main recipient of international aid. Afghanistan and Iraq, suffering from wars and political regime changes, ranked $5^{\text {th }}$ and $1^{\text {st }}$. These changes reflected the potential shift of motivation of donor countries. 
Table 5. Top 10 of different periods.

\begin{tabular}{|c|c|c|c|}
\hline \multicolumn{2}{|c|}{ Before 1992} & \multicolumn{2}{|c|}{ After 1992} \\
\hline Country & Commitment & Country & Commitment \\
\hline ALL & 2194.9 & ALL & 898.4 \\
\hline Top 10 Donor & & Top 10 Donor & \\
\hline United States & 599.1 & United States & 258.9 \\
\hline Japan & 394.9 & Japan & 167.0 \\
\hline Germany & 231.9 & Germany & 99.2 \\
\hline France & 172.5 & France & 61.0 \\
\hline United Kingdom & 119.2 & Canada & 41.3 \\
\hline Netherlands & 99.5 & United Kingdom & 39.6 \\
\hline Canada & 67.8 & Sweden & 34.8 \\
\hline Norway & 62.6 & Netherlands & 34.4 \\
\hline Australia & 60.0 & Italy & 29.4 \\
\hline Sweden & 56.2 & Australia & 23.7 \\
\hline Number of Donors & 47 & Number of Donors & 26 \\
\hline Top 10 Recipients & & Top 10 Recipients & \\
\hline Egypt & 65.8 & Iraq & 85.3 \\
\hline India & 57.4 & China & 84.3 \\
\hline Indonesia & 56.4 & Indonesia & 78.1 \\
\hline Israel & 37.6 & India & 76.6 \\
\hline Bangladesh & 36.3 & Afghanistan & 54.7 \\
\hline Pakistan & 33.3 & Russian Federation & 53.0 \\
\hline China & 26.6 & Egypt & 50.0 \\
\hline Philippines & 24.6 & Viet Nam & 48.8 \\
\hline Turkey & 21.5 & Pakistan & 42.1 \\
\hline U.R. of Tanzania: Mainland & 21.1 & Philippines & 41.9 \\
\hline Number of Recipients & 234 & Number of Recipients & 212 \\
\hline
\end{tabular}

Note: data source: AIDDATA (www.Aiddata.org); commitment in billion USD in 2011 constant price.

Our dataset also provides information on purpose on each aid flow. According to purpose code we select four main coarse categories of aid flows, that is, aid on social infrastructure and services, aid on economic infrastructure, aid on production sectors and aid on emergency assistances. Among social infrastructure there include education, health, population, water and government. Among economic infrastructure there include transport and storage, communications, energy generation and supply, banking and financing and business. Production sectors include agriculture and industry. There are also other purposes such as environment, general budget support and food aid. But consider the observa- 
tions are not so large, we do not independently observe their effects. Time trend of total amount of each category is shown in Figure 1. Social infrastructure has a steadily increasing trend, while economic infrastructure experienced a cool down period since 2000, which shared similar patterns with production sectors. Emergency assistance, surprisingly, has a small share and is rather flat. It does not necessarily indicate that emergency assistance did not increase for the same scale may flatten the trend. Nevertheless, the share obviously dropped. Based on this general information of each category, we conduct regression pair fixed effect regression on each type. The results of each type of aid flows are summarized in Table 6.

As predicted, the role of fixed exchange rate regime is robust in the first three categories. But emergency assistance aid flows, with no surprise, does not share the same effect. For control variables, the coefficients are reasonable in each category. For emergency assistance, many people suffering and poor facilities obviously matter. Political concerns are weak here. For economic infrastructure and production sectors, supporting economic institutions, such as human capital, are important for the success of the aid project. Therefore, the higher GDP

Table 6. Different categories of aid flows.

\begin{tabular}{|c|c|c|c|c|}
\hline VARIABLES & $\begin{array}{c}(1) \\
\text { Social } \\
\text { Infrastructure }\end{array}$ & $\begin{array}{c}(2) \\
\text { Economic } \\
\text { Infrastructure }\end{array}$ & $\begin{array}{c}\text { (3) } \\
\text { Production } \\
\text { Sectors }\end{array}$ & $\begin{array}{c}(4) \\
\text { Emergency } \\
\text { Assistance }\end{array}$ \\
\hline \multirow[t]{2}{*}{ Fixed ER } & $0.168^{\star * *}$ & $0.155^{\star * *}$ & $0.143^{* * *}$ & $-0.288^{* * *}$ \\
\hline & $(0.0287)$ & $(0.0518)$ & $(0.0416)$ & $(0.0501)$ \\
\hline \multirow[t]{2}{*}{ Chinn-Ito Index } & $0.0258^{\star *}$ & $0.0420^{*}$ & $-0.0409^{* *}$ & 0.00198 \\
\hline & $(0.0126)$ & $(0.0231)$ & $(0.0182)$ & $(0.0233)$ \\
\hline \multirow[t]{2}{*}{ GDP per capita } & -0.0257 & $0.347^{\star * *}$ & $0.140^{* *}$ & $-0.628^{* * *}$ \\
\hline & $(0.0374)$ & $(0.0732)$ & $(0.0570)$ & $(0.0716)$ \\
\hline \multirow[t]{2}{*}{ Population } & $1.428^{* * *}$ & 0.398 & $1.475^{\star * *}$ & $2.450^{* * *}$ \\
\hline & $(0.150)$ & $(0.273)$ & $(0.219)$ & $(0.275)$ \\
\hline \multirow[t]{2}{*}{ Democracy } & $0.0769^{*}$ & $0.345^{\star * *}$ & $0.233^{* * *}$ & $0.123^{*}$ \\
\hline & $(0.0393)$ & $(0.0738)$ & $(0.0575)$ & $(0.0677)$ \\
\hline \multirow[t]{2}{*}{ Political Rights } & $0.0890^{* *}$ & 0.0808 & $0.130^{* *}$ & -0.00322 \\
\hline & $(0.0365)$ & $(0.0673)$ & $(0.0533)$ & $(0.0648)$ \\
\hline \multirow[t]{2}{*}{ Constant } & $11.49^{* * *}$ & $11.93^{\star * *}$ & $10.80^{* * *}$ & $14.31^{* * *}$ \\
\hline & $(0.485)$ & (1.015) & $(1.976)$ & $(1.009)$ \\
\hline Observations & 30,686 & 16,591 & 18,628 & 13,277 \\
\hline $\mathrm{R}$-squared & 0.023 & 0.152 & 0.154 & 0.055 \\
\hline Number of Pairs & 3150 & 2284 & 2208 & 2223 \\
\hline
\end{tabular}

Note: Dependent variable is $\log$ values of aid flows. Standard errors in parentheses. ${ }^{* *} p<0.01,{ }^{* *} p<0.05$, ${ }^{*} p<0.1$. 
per capita, the more aid of these categories. Therefore, our model reflects the aid allocation of real world.

\subsection{Further Estimation: Trade Interest}

Since the previous sections have demonstrated that fixed exchange rate will significantly increase the bilateral aid received from a certain donor, we further try to estimate why donors prefer delivering aid to those countries with fixed exchange rate, we put forward the following hypothesis: fixed exchange rate decreases the risk of fluctuating trade interest due to recipient countries' domestic conditions. The higher the trade volume, the greater the impact of fixed exchange rate on bilateral aid. In order to test the hypothesis, we include trade value and the cross term of trade value and fixed exchange rate regime, as shown in Equation (2).

$$
\begin{aligned}
& A i d_{i j t} \\
= & \beta_{1} \text { Capital Openess }+\beta_{2} \text { Exchange Rate Regime }+\beta_{3} \text { Fixed Exchangerate } \\
& * \text { Trade Value }+\beta_{4} \text { Trade Value }+\beta_{5} \text { Control Varibales }+\alpha_{j} \\
= & \alpha_{t}=\mu_{i j t}
\end{aligned}
$$

In Table 7, we add the cross term of fixed exchange rate regime with import value, export value and bilateral values.

While all effects of fixed exchange rate remain significantly positive, the significance of cross term varies among measures of trade values. When the recipient countries export more from the donor countries, the effect of fixed exchange rate regime on aid flows enlarge more. On mean value of export value, for example, recipient countries with fixed exchange rate regime receive $16.3 \%$ (= $12.6 \%+0.939 \%$ * 3.9$)$ more than countries with floated exchange rate regime. But this is not the case for import value from donor countries. The cross term of import value and fixed exchange rate regime is only significant on $10 \%$ level. The coefficient is also smaller. This seems to support the effect works in mainly through exporting interest. We can conclude that the effect of fixed exchange rate policy on the aid allocation increases with trade volume. Fixed exchange rate tends to decrease the risk of domestic fluctuating exchange rates; thus, increase the security of trade interests. However, it is imprecise to conclude that the effect of fixed exchange rate relies on donor countries' trading interest for the cross term estimation is not causal analysis.

\section{Conclusion}

Whether the allocation of international aid is biased to recipient countries' exchange rate regime and capital openness? Our answer significantly is yes for exchange rate regime, and little evidence to be distinguished from zero for capital openness. Using a comprehensive dataset of bilateral aid records, we find that recipient countries with fixed exchange rate regime are more likely to receive a larger amount of commitment. This effect is robust whether or not controlling 
Table 7. Effects of exchange rate regime with trade values.

\begin{tabular}{|c|c|c|c|}
\hline Variables & (1) & (2) & (3) \\
\hline \multirow[t]{2}{*}{ Fixed ER } & $0.134^{\star * \star}$ & $0.141^{\star * *}$ & $0.126^{\star * *}$ \\
\hline & $(0.0307)$ & $(0.0304)$ & $(0.0301)$ \\
\hline \multirow[t]{2}{*}{ Bilateral Trade Value * Fixed ER } & $0.00699^{\star *}$ & & \\
\hline & $(0.00338)$ & & \\
\hline \multirow[t]{2}{*}{ Bilateral Trade Value } & -0.00425 & & \\
\hline & $(0.00354)$ & & \\
\hline \multirow[t]{2}{*}{ Import From Donor ${ }^{\star}$ Fixed ER } & & $0.00604^{*}$ & \\
\hline & & $(0.00359)$ & \\
\hline \multirow[t]{2}{*}{ Import From Donor } & & -0.00344 & \\
\hline & & $(0.00368)$ & \\
\hline \multirow[t]{2}{*}{ Export To Donor ${ }^{\star}$ Fixed ER } & & & $0.00939^{* * *}$ \\
\hline & & & $(0.00360)$ \\
\hline \multirow[t]{2}{*}{ Export to Donor } & & & -0.00407 \\
\hline & & & $(0.00360)$ \\
\hline \multirow[t]{2}{*}{ Chinn-Ito index } & 0.00204 & 0.00269 & 0.00165 \\
\hline & $(0.0105)$ & $(0.0105)$ & $(0.0105)$ \\
\hline \multirow[t]{2}{*}{ GDP per capita } & $-0.123^{\star * *}$ & $-0.124^{\star \star \star}$ & $-0.122^{\star \star \star}$ \\
\hline & $(0.0294)$ & $(0.0294)$ & $(0.0294)$ \\
\hline \multirow[t]{2}{*}{ Population } & $1.679^{* * *}$ & $1.675^{* * *}$ & $1.677^{* * *}$ \\
\hline & $(0.117)$ & $(0.117)$ & $(0.117)$ \\
\hline \multirow[t]{2}{*}{ Democracy } & $0.158^{\star * *}$ & $0.158^{\star * *}$ & $0.158^{\star * *}$ \\
\hline & $(0.0338)$ & $(0.0338)$ & $(0.0338)$ \\
\hline \multirow[t]{2}{*}{ Political Rights } & $0.143^{* * *}$ & $0.144^{\star * *}$ & $0.142^{\star * *}$ \\
\hline & $(0.0311)$ & $(0.0311)$ & $(0.0310)$ \\
\hline \multirow[t]{2}{*}{ Constant } & $13.65^{\star * *}$ & $13.67^{\star * *}$ & $13.64^{\star * *}$ \\
\hline & $(1.291)$ & $(1.291)$ & $(1.291)$ \\
\hline Year Fixed Effects & Y & $\mathrm{Y}$ & $\mathrm{Y}$ \\
\hline Donor-Recipient Pair Fixed Effects & $\mathrm{Y}$ & $\mathrm{Y}$ & $\mathrm{Y}$ \\
\hline Observations & 43,461 & 43,461 & 43,461 \\
\hline R-squared & 0.722 & 0.722 & 0.722 \\
\hline
\end{tabular}

Note: Dependent variable is log values of aid flows. Standard errors in parentheses. ${ }^{* *} p<0.01,{ }^{* *} p<0.05$, ${ }^{\star} p<0.1$.

for different kinds of control variables and fixed effects. In our further exploration of interaction between exchange rate regime and bilateral trade values, we strengthen our hypothesis. Bilateral trade interest may be a potential explanation of the effects. Donor countries tend to allocate more aid flows to recipient coun- 
tries with fixed exchange rate regime because fixed exchange regime makes the trade less risky and therefore, the expected trade interest is larger for these countries. Donor countries may have the motivation to allocate more aid flows to these countries, for aid may facilitate their trade activities, especially exports, in the recipient county.

The effect of capital openness, however, is only significant without controlling donor-recipient pair fixed effects. Once country pair fixed effects are controlled, the capital openness of the recipient countries has no significant effects on how much aid flows they would receive. This implies that some time-invariant pair relationship factor, instead, is the driver of the effects.

This difference may have further implications. Based on our intuition, we can assume that exchange rate regime is more directly related to trade interest of donor countries, and capital openness matter more for investment interest. Then, this contrast also implies that aid may facilitate short-term trade interest rather than long-term investment interest. Therefore, when considering how much to support the recipient countries, donor countries care more about trade interest and less about investment interest.

This paper contributes the long literature on how aid flows are allocated besides the economic condition of the recipients. The issue of foreign aid is never merely about the poorer countries which received more. Economic and political interests of donor countries play important roles. In particular, this paper emphasizes that the role of exchange rate regime of the recipient countries matters, too. And trade interest of donor countries is the possible explanation for this effect.

However, there exist some limitations in our study. The main challenge here is whether we can go beyond the scope of correlation study to maintain a more substantial and insightful explanation of this correlation. Previous researchers stated that the empirical literature on aid effectiveness had suffered from "the heterogeneity of aid motives, the limitation of the tolls of analysis, and the complex causality chains" (Bourguignon \& Sundberg, 2007). Although we attempt to explain the effect of fixed exchange rate by trade interests, the cross-term model is indirect and inconclusive. This is beyond the exploration of this paper and waits for further research.

\section{Conflicts of Interest}

The authors declare no conflicts of interest regarding the publication of this paper.

\section{References}

Aizenman, J., Chinn, M. D., \& Ito, H. (2013). The "Impossible Trinity" Hypothesis in an Era of Global Imbalances: Measurement and Testing: The "Impossible Trinity" Hypothesis. Review of International Economics, 21, 447-458.

https://doi.org/10.1111/roie.12047 
Alesina, A., \& Dollar, D. (1998). Who Gives Foreign Aid to Whom and Why. Journal of Economic Growth, 5, 33-63. https://doi.org/10.1023/A:1009874203400

Alesina, A., \& Weder, B. (2002). Do Corrupt Governments Receive Less Foreign Aid? American Economic Review, 92, 1126-1137. https://doi.org/10.1257/00028280260344669

Berthélemy, J.-C. (2006). Bilateral Donors' Interest vs. Recipients' Development Motives in Aid Allocation: Do All Donors Behave the Same? Review of Development Economics, 10, 179-194. https://doi.org/10.1111/j.1467-9361.2006.00311.x

Boix, C., Miller, M., \& Rosato, S. (2013). A Complete Data Set of Political Regimes, 1800-2007. Comparative Political Studies, 46, 1523-1554.

https://doi.org/10.1177/0010414012463905

Bourguignon, F., \& Sundberg, M. (2007). Aid Effectiveness: Opening the Black Box. The American Economic Review, 97, 316-321. https://doi.org/10.1257/aer.97.2.316

Burnside, A. C., \& Dollar, D. (2004). Aid, Policies, and Growth: Revisiting the Evidence. SSRN Scholarly Paper ID 610292, Rochester, NY: Social Science Research Network. https://doi.org/10.1596/1813-9450-3251

Chinn, M. D., \& Ito, H. (2006). What Matters for Financial Development? Capital Controls, Institutions, and Interactions. Journal of Development Economics, 81, 163-192. https://doi.org/10.1016/j.jdeveco.2005.05.010

Clemens, M. A., Radelet, S., Bhavnani, R. R., \& Bazzi, S. (2012). Counting Chickens When They Hatch: Timing and the Effects of Aid on Growth. The Economic Journal, 122, 590-617. https://doi.org/10.1111/j.1468-0297.2011.02482.x

Dollar, D., \& Levin, V. (2006). The Increasing Selectivity of Foreign Aid, 1984-2003. World Development, 34, 2034-2046. https://doi.org/10.1016/j.worlddev.2006.06.002

Dowling, J. M., \& Hiemenz, U. (1985). Biases in Allocation of Foreign Aid: Some New Evidence. World Development, 13, 535-541. https://doi.org/10.1016/0305-750X(85)90055-5

Dreher, A., \& Fuchs, A. (2015). Rogue Aid? An Empirical Analysis of China's Aid Allocation. Canadian Journal of Economics, 48, 988-1023. https://doi.org/10.1111/caje.12166

Easterly, W. (2003). Can Foreign Aid Buy Growth? The Journal of Economic Perspectives, 17, 23-48. https://doi.org/10.1257/089533003769204344

Faye, M., \& Niehaus, P. (2012). Political Aid Cycles. American Economic Review, 102, 3516-3530. https://doi.org/10.1257/aer.102.7.3516

Feenstra, R. C., Lipsey, R. E., Deng, H. Y., Ma, A. C., \& Mo, H. Y. (2004). World Trade Flows: 1962-2000. NBER Working Paper No. 11040. https://doi.org/10.3386/w11040

Freedom House (2015). Freedom in the World: Aggregate and Subcategory Scores. https://freedomhouse.org/report/freedom-world-aggregate-and-subcategory-scores

Fuchs, A., \& Vadlamannati, K. C. (2013). The Needy Donor: An Empirical Analysis of India's Aid Motives. World Development, 44, 110-128. https://doi.org/10.1016/j.worlddev.2012.12.012

Hadenius, A., \& Teorell, J. (2007). Pathways from Authoritarianism. Journal of Democracy, 18, 143-157. https://doi.org/10.1353/jod.2007.0009

Hansen, H., \& Tarp, F. (2001). Aid and Growth Regressions. Journal of Development Economics, 64, 547-570. https://doi.org/10.1016/S0304-3878(00)00150-4

Hoeffler, A., \& Outram, V. (2011). Need, Merit, or Self-Interest-What Determines the Allocation of Aid? Review of Development Economics, 15, 237-250.

https://doi.org/10.1111/j.1467-9361.2011.00605.x 
Kilby, C. (2013). The Political Economy of Project Preparation: An Empirical Analysis of World Bank Projects. Journal of Development Economics, 105, 211-225. https://doi.org/10.1016/j.jdeveco.2013.07.011

Kuziemko, I., \& Werker, E. (2006). How Much Is a Seat on the Security Council Worth? Foreign Aid and Bribery at the United Nations. Journal of Political Economy, 114, 905-930. https://doi.org/10.1086/507155

Lee, H.-H., Park, D., \& Shin, M. (2015). Do Developing-Country WTO Members Receive More Aid for Trade (AfT)? The World Economy, 38, 1462-1485. https://doi.org/10.1111/twec.12258

Levy-Yeyati, E., \& Sturzenegger, F. (2005). Classifying Exchange Rate Regimes: Deeds vs. Words. European Economic Review, 49, 1603-1635. https://doi.org/10.1016/j.euroecorev.2004.01.001

Maizels, A., \& Nissanke, M. (1984). Motivations for Aid to Developing Countries. World Development, 12, 879-900. https://doi.org/10.1016/0305-750X(84)90046-9

McKinlay, R. D., \& Little, R. (1979). The U.S. Aid Relationship: A Test of the Recipient Need and the Donor Interest Models. Political Studies, 27, 236-250. https://doi.org/10.1111/j.1467-9248.1979.tb01201.x

Neumayer, E. (2003). The Determinants of Aid Allocation by Regional Multilateral Development Banks and United Nations Agencies. International Studies Quarterly, 47, 101-122. https://doi.org/10.1111/1468-2478.4701005

Neumayer, E. (2005). Is the Allocation of Food Aid Free from Donor Interest Bias? Journal of Development Studies, 41, 394-411. https://doi.org/10.1080/0022038042000313309

Rajan, R. G., \& Subramanian, A. (2008). Aid and Growth: What Does the Cross-Country Evidence Really Show? Review of Economics and Statistics, 90, 643-665. https://doi.org/10.1162/rest.90.4.643

Ram, R. (2004). Recipient Country's “Policies” and the Effect of Foreign Aid on Economic Growth in Developing Countries: Additional Evidence. Journal of International Development, 16, 201-211. https://doi.org/10.1002/jid.1071

Reinhart, C., \& Rogoff, K. (2004). The Modern History of Exchange Rate Arrangements: A Reinterpretation. Quarterly Journal of Economics, 119, 1-48. https://doi.org/10.1162/003355304772839515

Reinsberg, B. (2015). Foreign Aid Responses to Political Liberalization. World Development, 75, 46-61. https://doi.org/10.1016/j.worlddev.2014.11.006

Snyder, D. W. (1993). Donor Bias towards Small Countries: An Overlooked Factor in the Analysis of Foreign Aid and Economic Growth. Applied Economics, 25, 481-488. https://doi.org/10.1080/00036849300000056

Stubbs, T. H., Kentikelenis, A. E., \& King, L. P. (2015). Catalyzing Aid? The IMF and Donor Behavior in Aid Allocation. World Development, 78, 511-528. https://doi.org/10.1016/j.worlddev.2015.10.010

Svensson, J. (1999). Aid, Growth and Democracy. Economics and Politics, 11, 275-297. https://doi.org/10.1111/1468-0343.00062

Tierney, M. J., Nielson, D. L., Darren, G. H., Roberts, J. T., Findley, M. G., Powers, R. M., Parks, B., Wilson, S. E., \& Hicks, R. L. (2011). More Dollars than Sense: Refining Our Knowledge of Development Finance Using AidData. World Development, 39, 1891-1906. https://doi.org/10.1016/j.worlddev.2011.07.029 


\section{Appendix}

Table added: Benchmark results without capital openness.

\begin{tabular}{|c|c|c|c|c|c|}
\hline & (1) & (2) & (3) & $(4)$ & (5) \\
\hline \multirow[t]{2}{*}{ Fixed ER } & $0.148^{* * *}$ & $0.0852^{\star * *}$ & $0.108^{* * *}$ & & $0.197^{\star \star \star}$ \\
\hline & $(0.0261)$ & $(0.0219)$ & $(0.0215)$ & & $(0.0233)$ \\
\hline \multirow[t]{2}{*}{ Lagged Fixed ER } & & & & $0.0985^{\star * *}$ & \\
\hline & & & & $(0.0213)$ & \\
\hline \multirow[t]{2}{*}{ GDP per capita } & $-0.343^{\star \star *}$ & $-0.363^{\star * *}$ & $-0.382^{\star * \star}$ & $-0.383^{\star * \star}$ & $-0.153^{* * *}$ \\
\hline & $(0.0126)$ & $(0.0106)$ & $(0.0108)$ & $(0.0108)$ & $(0.0287)$ \\
\hline \multirow[t]{2}{*}{ Population } & $0.769^{* * *}$ & $0.850^{* * *}$ & $0.891^{* * *}$ & $0.891^{* * *}$ & $1.504^{\star * *}$ \\
\hline & $(0.0134)$ & $(0.0114)$ & $(0.0116)$ & $(0.0116)$ & $(0.109)$ \\
\hline \multirow[t]{2}{*}{ Democracy } & & & $0.157^{\star * *}$ & $0.156^{* * *}$ & $0.164^{* * *}$ \\
\hline & & & $(0.0319)$ & $(0.0319)$ & $(0.0333)$ \\
\hline \multirow[t]{2}{*}{ Political Rights } & & & $0.131^{* * *}$ & $0.130^{* * *}$ & $0.129^{\star * \star}$ \\
\hline & & & $(0.0317)$ & $(0.0317)$ & $(0.0301)$ \\
\hline \multirow[t]{2}{*}{ Colonial Connection } & & & $2.290^{* * *}$ & $2.290^{* * *}$ & \\
\hline & & & $(0.0506)$ & $(0.0506)$ & \\
\hline \multirow[t]{2}{*}{ Constant } & $16.73^{\star * *}$ & $20.04^{\star * *}$ & $20.01^{* * *}$ & $20.02^{\star * *}$ & $15.76^{\star * *}$ \\
\hline & $(0.110)$ & $(2.087)$ & $(2.029)$ & $(2.029)$ & $(1.563)$ \\
\hline Year Fixed Effects & $\mathrm{Y}$ & $\mathrm{Y}$ & $\mathrm{Y}$ & $\mathrm{Y}$ & $\mathrm{Y}$ \\
\hline Donor Fixed Effects & $\mathrm{N}$ & $\mathrm{Y}$ & $\mathrm{Y}$ & $\mathrm{Y}$ & $\mathrm{N}$ \\
\hline $\begin{array}{l}\text { Donor-Recipient Pair } \\
\text { Fixed Effects }\end{array}$ & $\mathrm{N}$ & $\mathrm{N}$ & $\mathrm{N}$ & $\mathrm{N}$ & $\mathrm{Y}$ \\
\hline Observations & 45,389 & 45,389 & 44,827 & 44,827 & 44,827 \\
\hline R-squared & 0.153 & 0.405 & 0.438 & 0.438 & 0.719 \\
\hline
\end{tabular}

